\title{
South East Europe: Trade Liberalization, Economic Integration, Quality, Security and Guarantee of Products and Services
}

\author{
Enriko Ceko \\ Universiteti Planetar $\mathrm{T}$ Tiranës \\ Tel: 00355692029631 \\ enrikoceko@yahoo.co.uk
}

\section{Doi:10.5901/mjss.2013.v4n9p494}

\begin{abstract}
The strengthening of security and the political situation, intensification of economic relations and co-operation in the areas of human resources, democracy, justice, battle against illegal activities, are the intentions of Southeast Countries to enable approaching the European/EuroAtlantic structures, strengthening good neighborly relations \& transformation the region into an area of peace \& stability. This requires trade liberalization, economic integration, quality, security, guarantee of products \& services, removal or reduction of trade practices that thwart free flow of goods and services, includes dismantling of tariff \& non tariff barriers, unification of economic policies between countries through the partial or full abolition of trade tariff and non-tariff restrictions, leading for lower prices, increasing the combined countries economic productivity, achieving product/service's customer's expectations, achieving the state of being "safe" against physical, social, spiritual, financial, political, emotional, occupational, psychological, educational and other types/consequences of failure, damage, error, accidents, harm, other events which could be considered non-desirable, having the control of recognized hazards to achieve an acceptable level of risk, being protected from the event or from exposure to something that causes health/economical losses. Continuous changes in developing economy, technology, environmental regulation and public safety concerns are the main areas where SEE countries are focused for their common future, using their human \& natural resources.
\end{abstract}

Keywords: Trade liberalization, economic integration, products, services,

\section{South East Europe}

There are four possible definitions of "Southeastern Europe".

1. The Balkan Peninsula south of the River Danube-River Sava-River Kupa line

2. The European territories of the former Ottoman Empire

3. The substantially larger space with a northern delineation that respects actual borders, promoted by the European Union from 1999

4. The European Union co-funded regional development model that adds Austria, the eastern Regions of Italy and southwestern Ukraine.

In this article the last model will be taken into the consideration.

\subsection{Southeast Europe \& Southeast Europe transnational co-operation program model}

Southeast Europe is a relatively recent political designation mostly for the states of the Balkans (1). The first known usage of the term 'Southeast Europe' was by Austrian researcher Johann Georg von Hahn (1811-1869) as broader term than the traditional Balkans (2). The Southeast Europe transnational co-operation program "aims to develop transnational partnerships on matters of strategic importance, in order to improve the territorial, economic and social integration process and to contribute to cohesion, stability and competitiveness of the region" (3)

The members include: Albania, Austria, Bosnia and Herzegovina, Bulgaria, Croatia, Republic of Macedonia, Greece, Hungary, Republic of Moldova, Montenegro, Romania, Serbia, Slovakia, Slovenia, and some regions of Italy and Ukraine (4) 
Table 1. Main figures of SEE countries (Drawn from author of the article using Wikipedia's data.)

\begin{tabular}{|c|l|c|c|c|c|}
\hline No & Country & Area $(\mathbf{k m} 2)$ & Population & GDP (USD) & HDI \\
\hline $\mathbf{1}$ & Albania & 28.748 & 3.000 .000 & 8.000 & 0.739 \\
\hline $\mathbf{2}$ & Austria & 83.555 & 8.500 .000 & 49.800 & 0.885 \\
\hline $\mathbf{3}$ & Bosnia \& Herzegovina & 51.197 & 3.800 .00 & 8.000 & 0733 \\
\hline $\mathbf{4}$ & Bulgaria & 110.994 & 7.400 .000 & 13.500 & 0.771 \\
\hline $\mathbf{5}$ & Croatia & 56.594 & 4.300 .000 & 18.200 & 0.796 \\
\hline $\mathbf{6}$ & Republic of Macedonia & 25.713 & 2.000 .000 & 10.300 & 0.728 \\
\hline $\mathbf{7}$ & Greece & 131.990 & 10.800 .000 & 26.300 & 0.861 \\
\hline $\mathbf{8}$ & Hungary & 93.030 & 9.940 .000 & 19.600 & 0.816 \\
\hline $\mathbf{9}$ & Kosovo & 10.908 & 1.800 .000 & 7.000 & $\mathrm{~N} / \mathrm{A}$ \\
\hline $\mathbf{1 0}$ & Republic of Moldova & 33.846 & 3.600 .000 & 3.400 & 0.649 \\
\hline $\mathbf{1 1}$ & Montenegro & 13.812 & 630.000 & 11.600 & 0.771 \\
\hline $\mathbf{1 2}$ & Romania & 238.391 & 19.000 .000 & 12.500 & 0.781 \\
\hline $\mathbf{1 3}$ & Serbia & 77.652 & 7.200 .000 & 10.600 & 0.766 \\
\hline $\mathbf{1 4}$ & Slovakia & 49.035 & 5.500 .000 & 23.000 & 0.834 \\
\hline $\mathbf{1 5}$ & Slovenia & 20.273 & 2.000 .000 & 28.600 & 0.884 \\
\hline $\mathbf{1 6}$ & Some regions of Italy & $\mathrm{NA}$ & $\mathrm{NA}$ & 30.400 & 0.874 \\
\hline $\mathbf{1 7}$ & Ukraine & 603.628 & 45.900 .000 & 7.200 & 0.729 \\
\hline
\end{tabular}

We are talking for an area of about $1.630 .000 \mathrm{ml} \mathrm{km} 2$ (without Italian regions) and a population of about $135.5 \mathrm{ml}$ (without population of Italian regions) with a lot of natural and human resources.

\subsection{Southeast European Cooperation Process}

The South-East European Cooperation Process (SEECP) was launched on Bulgaria's initiative in 1996. At the Bulgariachaired meeting in Sofia, the SEE countries laid the foundations for regional co-operation for the purposes of creating an atmosphere of trust, good neighborly relations and stability. A special characteristic of SEECP is that it is an original form of co-operation among the countries in the region launched on their own initiative, and not on the initiative of some other international organization or countries. In that regard, the SEECP seeks to define itself as an authentic voice of SEE, complementary to the Stability Pact, SECI or the Stabilization and Association Process.

The basic goals of regional co-operation within SEECP include the strengthening of security and the political situation, intensification of economic relations and co-operation in the areas of human resources, democracy, justice, and battle against illegal activities. It is the intention of the SEECP to enable its members to approach the European and Euro-Atlantic structures through the strengthening of good neighborly relations and transformation of the region into an area of peace and stability.

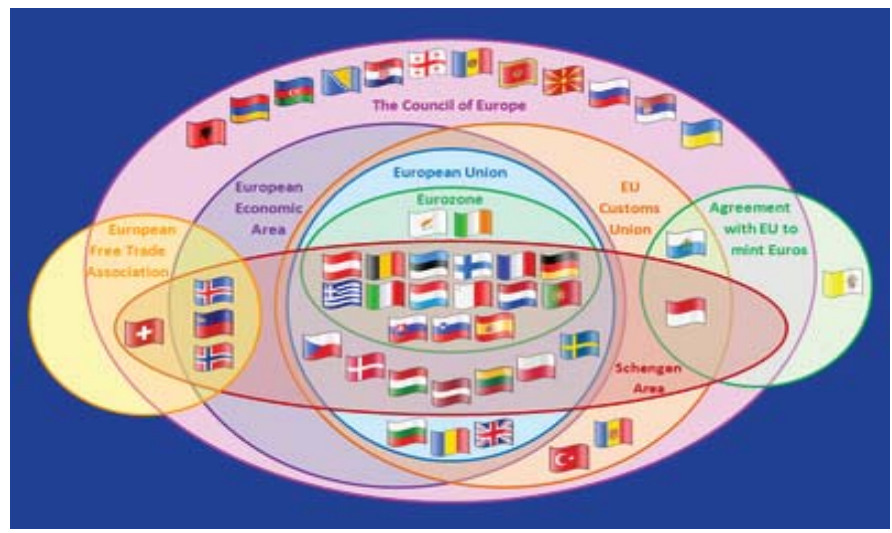

Figure 1. Supranational European Bodies

Source: http://en.wikipedia.org/wiki/EuropeanEconomicArea) 


\subsection{Business opportunities in the SEE area}

Since the area is full of natural and human resources business opportunities may arise in all sectors, but agricultural production, agribusiness, textile and leather manufacturing, minerals and metals industry, energy and hydrocarbon production and trade, pharmaceuticals, consultancy, etc, are promising sectors. These sectors require investments on achieving competitive advantage towards production specialization. For example Ukraine and Kosovo may be specialized on whit production, Albania and Greece on olives and olives oil production, Albania in watermelon production, Albania, Republic of Macedonia and Greece on milk processing and wine, Austria on hydrocarbon processing and vehicles manufacturing, Slovakia and Ukraine on minerals, Romania, Albania and Ukraine on fuel reserves and exploitation, etc.

\section{Trade liberalization}

With concept of "trade liberalization" we understand today the removal of or reduction in the trade practices that thwart free flow of goods and services from one nation to another. It includes dismantling of tariff (such as duties, surcharges, and export subsidies) as well as non tariff barriers, such as licensing regulations, quotas, and arbitrary standards) (5).

\subsection{Current situation on trade liberalization}

Recent decades have seen rapid growth of the world economy. This growth has been driven in part by the even faster rise in international trade. The growth in trade is in turn the result of both technological developments and concerted efforts to reduce trade barriers. Some developing countries have opened their own economies to take full advantage of the opportunities for economic development through trade, such as South European Countries, but not for all goods, services, capitals and humans (6). Still between these countries remaining trade barriers industry, agricultural products, etc, because of having comparative advantage. Further trade liberalization in these areas particularly, by both industrial and developing countries, would help some of these countries escape from low level incomes while also benefiting the high income countries themselves (7).

\subsection{The Benefits of Trade Liberalization}

Policies that make an economy open to trade and investment with the rest of the world are needed for sustained economic growth. The evidence on this is clear. No country in recent decades has achieved economic success, in terms of substantial increases in living standards for its people, without being open to the rest of the world. In contrast, trade opening (along with opening to foreign direct investment) has been an important element in the economic success of Southeast Europe area, where the average import tariff has fallen from 30 percent to 10 percent over the past 20 years (8).

Opening up their economies to the global economy has been essential in enabling South East Europe countries to develop competitive advantages in the manufacture of certain products. Such countries would gain more from global trade liberalization as a percentage of their GDP than industrial countries, because their economies are more highly protected and because they face higher barriers. Although there are benefits from improved access to other countries' markets, countries benefit most from liberalizing their own markets. The main benefits for industrial countries would come from the liberalization of their agricultural markets. Developing countries would gain about equally from liberalization of manufacturing and agriculture. The group of low-income countries, however, would gain most from agricultural liberalization in industrial countries because of the greater relative importance of agriculture in their economies.

\subsection{Disadvantages of tariffs}

The chart below analyzes the effect of the imposition of an import tariff on some imaginary good. Prior to the tariff, the price of the good in the world market (and hence in the domestic market) is Pworld. The tariff increases the domestic price to Ptariff. The higher price causes domestic production to increase from QS1 to QS2 and causes domestic consumption to decline from QC1 to QC2 (9). This has three main effects on societal welfare. Consumers are made worse off because the consumer surplus (green region) becomes smaller. Producers are better off because the producer 
surplus (yellow region) is made larger. The government also has additional tax revenue (blue region). However, the loss to consumers is greater than the gains by producers and the government. The magnitude of this societal loss is shown by the two pink triangles. Removing the tariff and having free trade would be a net gain for society (9).

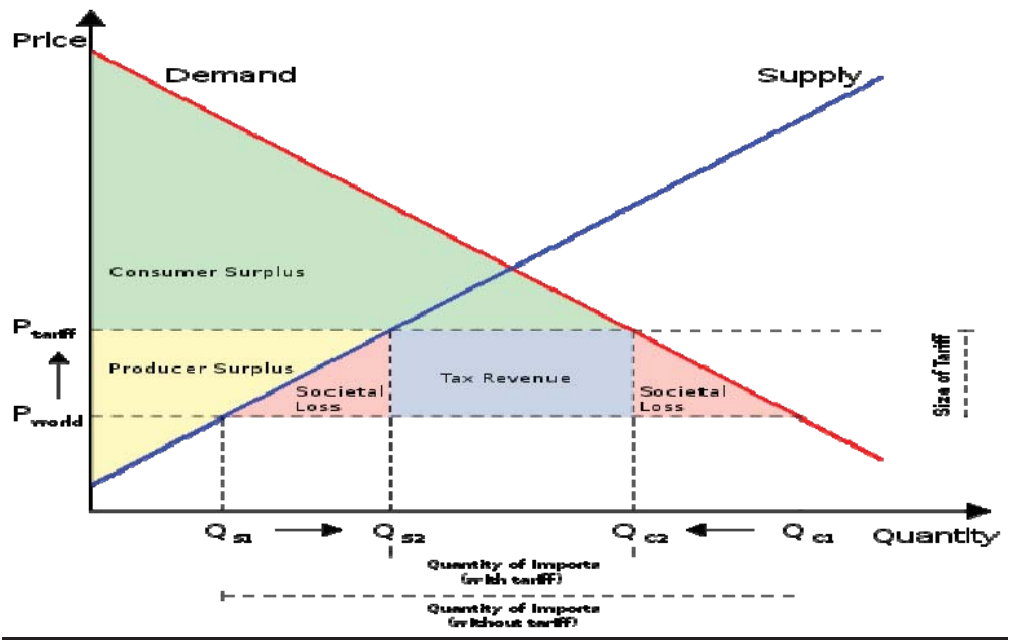

Graphic 1. Disadvantages of tariffs. The pink regions are the net loss to society caused by the existence of the tariff.

An almost identical analysis of this tariff from the perspective of a net producing country yields parallel results. From that country's perspective, the tariff leaves producers worse off and consumers better off, but the net loss to producers is larger than the benefit to consumers (there is no tax revenue in this case because the country being analyzed is not collecting the tariff). Under similar analysis, export tariffs, import quotas, and export quotas all yield nearly identical results. Free trade creates winners and losers, but theory and empirical evidence show that the size of the winnings from free trade are larger than the losses (10)

\subsection{Degree of free trade policies}

The Enabling Trade Index measures the factors, policies and services that facilitate the trade in goods across borders and to destination. It is made up of four sub-indexes: market access; border administration; transport and communications infrastructure; and business environment.

The top 20 countries are:

1. Singapore 6.06

2. Hong Kong 5.70

3. Denmark 5.41

4. Sweden 5.41

5. Switzerland 5.37

6. New Zealand 5.33

7. Norway 5.32

8. Canada 5.29

9. Luxembourg 5.28

10. Netherlands 5.26

11. Iceland 5.26

12. Finland 5.25

13. Germany 5.20

14. Austria 5.17

15. Australia 5.13

16. United Arab Emirates 5.12 
17. United Kingdom 5.06

18. Chile 5.06

19. United States 5.03

20. France 5.02

Source: World Economic Forum. "Rankings: Global Enabling Trade Report 2010".)

Between SEE countries, only Austria is included on the list of top 20 countries with free trade policies. There is still to much work to be done from SEE countries to achieve economic development of countries like Singapore, Hong Kong, Denmark, Sweden, Switzerland, etc, which are on top of the list.

\section{Economic integration}

In economics, the word "integration" was first employed in industrial organization to refer to combinations of business firms through economic agreements, cartels, concerns, trusts, and mergers-horizontal integration referring to combinations of competitors, vertical integration to combinations of suppliers with customers. In the current sense of combining separate economies into larger economic regions, the use of the word integration can be traced to the 1930s and 1940s (11) Eli Heckscher, Herbert Gaedicke and Gert von Eyern are the first users of the term economic integration in its current sense. Such usage first appears in the 1935 English translation of Hecksher's 1931 book Merkantilismen, and independently in Gaedicke's and von Eyern's 1933 two-volume study Die produktionswirtschaftliche Integration Europas: Eine Untersuchung über die Aussenhandelsverflechtung der europäischen Länder. (12)

\subsection{Economic integration}

Economic integration is the unification of economic policies between different states through the partial or full abolition of tariff and non-tariff restrictions on trade taking place among them prior to their integration. This is meant in turn to lead to lower prices for distributors and consumers with the goal of increasing the combined economic productivity of the states. The trade stimulation effects intended by means of economic integration are part of the contemporary economic Theory of the Second Best: where, in theory, the best option is free trade, with free competition and no trade barriers whatsoever. Free trade is treated as an idealistic option, and although realized within certain developed states, economic integration has been thought of as the "second best" option for global trade where barriers to full free trade exist.

\subsection{Objective}

The increase of trade between member states of economic unions is meant to lead to higher productivity. This is one of the reasons for the global scale development of economic integration, a phenomenon now realized in continental economic blocks such as ASEAN, NAFTA, SACN, the European Union, and the Eurasian Economic Community; and proposed for intercontinental economic blocks, such as the Comprehensive Economic Partnership for East Asia and the Transatlantic Free Trade Area, SEE, etc.

Comparative advantage refers to the ability of a person or a country to produce a particular good or service at a lower marginal and opportunity cost over another.

For example: In Albania it is possible to produce both olives oil and shoes with less labor than it would take to produce the same quantities in Austria and / or Slovenia. However the relative costs of producing those two goods are different in the two countries. In Austria and Slovenia it is very hard to produce olives oil, and only moderately difficult to produce shoes. In Albania both are easy to produce. Therefore while it is cheaper to produce shoes in Albania than Austria, it is cheaper still for Albania to produce excess olives oil, and trade that for Austrian shoes or vehicles. Conversely Austria benefits from this trade because its cost for producing shoes has not changed but it can now get olives oil at a lower price, closer to the cost of shoes. The conclusion drawn is that each country can gain by specializing in the good where it has comparative advantage, and trading that good for the other. 


\subsection{Economy of scale}

Economies of scale refer to the cost advantages that an enterprise obtains due to expansion. There are factors that cause a producer's average cost per unit to fall as the scale of output is increased. Economy of scale is a long run concept and refers to reductions in unit cost as the size of a facility and the usage levels of other inputs increase (13). Economies of scale is also a justification for economic integration, since some economies of scale may require a larger market than is possible within a particular country - for example, it would not be efficient for Kosovo to have its own car maker, if they would only sell to their local market. A lone car maker may be profitable, however, if they export cars to global markets in addition to selling to the local market (14)

The degree of economic integration can be categorized into seven stages:

- Preferential trading area

- Free trade area, Monetary union

- Customs union, Common market

- Economic union, Customs and monetary union

- Economic and monetary union

- Fiscal union

- Complete economic integration

These differ in the degree of unification of economic policies, with the highest one being the political union of the states.

\subsection{Free trade areas, custom union, monetary union, common market, economic union, fiscal union \& political union}

A "free trade area" (FTA) is formed when at least two states partially or fully abolish custom tariffs on their inner border. To exclude regional exploitation of zero tariffs within the FTA there is a rule of certificate of origin for the goods originating from the territory of a member state of an FTA.

A "customs union" introduces unified tariffs on the exterior borders of the union (CET, common external tariffs). A "monetary union" introduces a shared currency.

A "common market" add to a FTA the free movement of services, capital and labor.

An "economic union" combines customs union with a common market.

A "fiscal union" introduces a shared fiscal and budgetary policy. In order to be successful the more advanced integration steps are typically accompanied by unification of economic policies (tax, social welfare benefits, etc.), reductions in the rest of the trade barriers, introduction of supranational bodies, and gradual moves towards the final stage, a "political union" (15).

\subsection{Success factors}

Among the requirements for successful development of economic integration are "permanency" in its evolution (a gradual expansion and over time a higher degree of economic/political unification); "a formula for sharing joint revenues" (customs duties, licensing etc.) between member states (e.g., per capita); "a process for adopting decisions" both economically and politically; and "a will to make concessions" between developed and developing states of the union (16). A "coherence" policy is a must for the permanent development of economic unions, being also a property of the economic integration process. Historically the success of the European Coal and Steel Community opened a way for the formation of the European Economic Community (EEC) which involved much more than just the two sectors in the ECSC. So a coherence policy was implemented to use a different speed of economic unification (coherence) applied both to economic sectors and economic policies. Implementation of the coherence principle in adjusting economic policies in the member states of economic block causes economic integration effects (17).

\section{Quality, safety and guarantee}

Quality, safety and guarantee of products and services are the main issues related to concerns of consumers in SEE area. 


\subsection{Quality}

Quality in business, engineering and manufacturing has a pragmatic interpretation as the non-inferiority or superiority of something; it is also defined as fitness for purpose. Quality is a perceptual, conditional and somewhat subjective attribute and may be understood differently by different people. Consumers may focus on the specification quality of a product/service, or how it compares to competitors in the marketplace. Producers might measure the conformance quality, or degree to which the product/service was produced correctly. Support personnel may measure quality in the degree that a product is reliable, maintainable, or sustainable.

The dimensions of quality refer to the attributes that quality achieves in operations management.

- Quality supports dependability

- Dependability supports speed

- Speed supports flexibility

- Flexibility supports cost

Numerous definitions and methodologies have been created to assist in managing the quality-affecting aspects of business operations. Many different techniques and concepts have evolved to improve product or service quality. There are two common quality-related functions within a business. One is quality assurance which is the prevention of defects, such as by the deployment of a quality management system and preventative activities like failure mode and effects analysis (FMEA). The other is quality control which is the detection of defects, most commonly associated with testing which takes place within a quality management system typically referred to as verification and validation. These functions are common in Germany, Japan, UK, and other countries, but between SEE countries only Austria, Slovenia and in some points Slovenia and Greece are aware bout the issue. Quality management still remain problematic between private business subjects in Ukraine, Kosovo, Macedonia, Romania, Bulgaria, Albania, etc.

In these countries there are only a few number of companies which apply quality management techniques like Quality Management Systems, Total Quality Management (TQM), Design of Experiments, Continuous Improvement, Six Sigma, Statistical Process Control (SPC), Business Process Re-Engineering, Capability Maturity Models, etc.

\subsection{Safety}

Safety is the state of being "safe", the condition of being protected against physical, social, spiritual, financial, political, emotional, occupational, psychological, educational or other types or consequences of failure, damage, error, accidents, harm or any other event which could be considered non-desirable. Safety can also be defined to be the control of recognized hazards to achieve an acceptable level of risk. This can take the form of being protected from the event or from exposure to something that causes health or economical losses. It can include protection of people or of possessions.

Safety is the condition of a "steady state" of an organization or place doing what it is supposed to do. "What it is supposed to do" is defined in terms of public codes and standards, associated architectural and engineering designs, corporate vision and mission statements, and operational plans and personnel policies. For any organization, place, or function, large or small, safety is a normative concept. It complies with situation-specific definitions of what is expected and acceptable (18)

In the world of everyday affairs, not all goes as planned. Some entity's steady state is challenged. This is where security science, which is of more recent date, enters. Drawing from the definition of safety, then:

Security is the process or means, physical or human, of delaying, preventing, and otherwise protecting against external or internal, defects, dangers, loss, criminals, and other individuals or actions that threaten, hinder or destroy an organization's "steady state," and deprive it of its intended purpose for being.

Using this generic definition of safety it is possible to specify the elements of a security program. Security also called social safety or public safety, security is the risk of harm due to intentional criminal acts such as assault, burglary or vandalism. Because of the moral issues involved, security is of higher importance to many people than substantive safety. For example, a death due to murder is considered worse than a death in a car crash, even though in many countries, traffic deaths are more common than homicides. Safety measures are activities and precautions taken to improve safety, i.e. reduce risk related to human health (18).

Common safety measures include:

- Chemical analysis

- Destructive testing of samples 
- Drug testing of employees, etc.

- Examination of activities by specialists to minimize physical stress or increase productivity

- Geological surveys to determine whether land or water sources are polluted, how firm the ground is at a potential building site, etc.

- Government regulation so suppliers know what standards their product is expected to meet.

- Industry regulation so suppliers know what level of quality is expected. Industry regulation is often imposed to avoid potential government regulation.

- Instruction manuals explaining how to use a product or perform an activity

- Instructional videos demonstrating proper use of products. Root cause analysis to identify causes of a system failure and correct deficiencies.

- Periodic evaluations of employees, departments, etc.

- Physical examinations to determine whether a person has a physical condition that would create a problem.

In some point, it is evident to say member EU stated of CEE like Austria, Slovenia, etc are much better in these issues compare with other SEE countries, which are not members of EU, but this should be taken as an advantage to learn from.

\subsection{Guarantee}

Guarantee is anything that assures a certain outcome, but in terms of development the definition of Central Banks about reserves should be taken into the consideration. With this reserve guarantee a period of time which can be guaranteed with monetary reserves for buy of goods and services in case the country's economy fail under several circumstances should be understand. A reserve currency, or anchor currency, is a currency that is held in significant quantities by many governments and institutions as part of their foreign exchange reserves. It also tends to be the international pricing currency for products traded on a global market, and commodities such as oil, gold, etc. This permits the issuing country to purchase the commodities at a marginally lower rate than other nations, which must exchange their currencies with each purchase and pay a transaction cost. For major currencies, this transaction cost is negligible with respect to the price of the commodity. It also permits the government issuing the currency to borrow money at a better rate, as there will always be a larger market for that currency than others.

As per information recorded in Central Banks of CEE countries, most of them have monetary reserves no less than three months, which is a good indicator.

\section{Conclusions}

1. SEE countries initiative has improved economic development and politic stability in the region, but there is still too much to be done in terms of business development and using human and natural resources.

2. SEE countries should work on gaining competitive advantage through specialization of production and not simply through keeping trade barriers high, especially in those sectors where they have already fictive competitive advantage like in agriculture and minerals.

3. Quality, safety and guarantee of products and services remain a big issue for the future of SEE countries into the path of integration in EU and Euro-Atlantic structures.

\section{References}

John Lampe \& Palgrave Macmillan, 2005, Balkans into Southeastern Europe, Politics and culture in Southeastern Europe: The Balkan Studies Seminars in Olympia.

Hösch, Nehring, Sundhaussen (Hrsg.), 2009, Lexikon zur Geschichte Südosteuropas, S. 663, ISBN 3-8252-8270-8

About SE Europe TCP. 2011. Southeast-europe.net. Retrieved on 2011-07-24

Participating countries of SEETC-OP. 2011. Southeast-europe.net. Retrieved on 2011-07-24

http://www.businessdictionary.com/definition/trade-liberalization.html. 2012-09-04

World Bank, 2010. Globalization, Growth, and Poverty: Facts, Fears, and an Agenda for Action, forthcoming

IMF Report on trade liberalization 2012

Steven Matusz and David Tarr, 1999, "Adjusting to Trade Policy Reform", World Bank Policy Research Working Paper No. 2142, July 1999

Alan C. Stockamn. 2008. "Introduction to Economics" Second Edition Chapter 9 \& N. Gregory Mankiw "Macroeconomics" Fifth Edition 
Chapter 7

Steven E. Landsburg. 2008. "Price Theory and Applications" Sixth Edition Chapter 8

Fritz Machlup, 1977. Mercantilism. p3

Fritz Machlup, 1977. Mercantilism, p79

Sullivan, Arthur; Steven M. Sheffrin. 2003. Economics: Principles in action. Upper Saddle River, New Jersey 07458: Pearson Prentice Hall. pp. 157. ISBN 0-13-063085-3.

Balassa, B. 1967. Trade Creation and Trade Diversion in the European Common Market. The Economic Journal, vol. 77, pp. 1-21.

Dalimov R.T. 2008. Modeling international economic integration: an oscillation theory approach. Trafford, Victoria, 234 p \& Dalimov R.T. 2009. The dynamics of the trade creation and diversion effects under international economic integration, Current Research Journal of Economic Theory, vol. 1, issue 1 \& Dalimov R.T. 2011. Dynamics of international economic integration: non-linear analysis. Lambert Academic Publishing, 276 p.; ISBN 978-3-8433-6106-4, ISBN 3-8433-6106-1 \& Johnson, H. 1965. An Economic Theory of Protection, Tariff Bargaining and the Formation of Customs Unions. Journal of Political Economy, 1965, vol. 73, pp. 256-283 \& Johnson, H. 1965. Optimal Trade Intervention in the Presence of Domestic Distortions, in Baldwin et al., Trade Growth and the Balance of Payments, Chicago, Rand McNally, pp. 3-34 \& Jovanovich, M. 1998. International Economic Integration. Limits and Prospects. Second edition, Routledge

Ruiz Estrada, M. 2004. Global Dimension of Regional Integration Model (GDRI-Model). Faculty of Economics and Administration, University of Malaya. FEA-Working Paper, № 2004-7

Tinbergen, J. 1954. International Economic Integration. Amsterdam: Elsevier, \& Tovias, A. 1994. The Theory of Economic Integration: Past and Future. 2d ECSA-World conference "Federalism, Subsidies and Democracy in the European Union", Brussels, May 56, 1994, $10 \mathrm{p}$

Charles G. Oakes, PhD, 2009. Blue Ember Technologies, LLC. "Safety versus Security in Fire Protection Planning, "The American Institute of Architects: Knowledge Communities, May 2009. Retrieved on June 22, 2011 